\title{
ГОРОБЕЦЬ В.Ф.
}

Начіональний ботанічний сад ім. М.М. Гришка НАН Украӥни,

Україна, 01014, м. Київ, вул. Тімірязєвська, 1, е-таil: passer-w@yandex.иа, (066) 817-75-55

\section{СТВОРЕННЯ ВІТЧИЗНЯНИХ СОРТІВ ПІВОНІЇ З ВИКОРИСТАННЯМ МЕТОДУ ВІДДАЛЕНОЇ ГІБРИДИЗАЦІї}

Серед багаторічників, які зимують у відкритому грунті, півонії займають провідне місце, що зумовлено їх високою декоративністю, довговічністю і можливістю використовувати для озеленення та зрізу. Крім того, велика екологічна пластичність не тільки видів, але і більшості сортів дає змогу вирощувати ці рослини в різних кліматичних зонах.

Як білі, так і червоні форми Paeonia lactiflora Pall. вирощувалися в садах Китаю 3 536 року. Тут з'являються і перші сорти, оскільки розведення і вирощування півоній вважалося богоугодною справою. В Європу китайські сорти півонії були завезені на початку XVII століття. Найбільш популярними вони стають у Франції, і тут почалася інтенсивна селекційна робота зі створення нових сортів. Найвагоміших успіхів у цьому досягли французькі селекціонери N. Lemon, J. Calot, F. Crousse, V. Lemoine, Ch. Verdier, A. Dessert, A. Miellez. До нашого часу не втратили популярності такі їх сорти: 'Festiva Maxima', 'Edulis Superba', 'Philomele', 'Mons. Jules Elie', 'Felix Crousse', 'Albatre', 'Le Cygne', 'Mont Blanc', 'Sarah Bernhard', 'Solange' та інші, які були інтродуковані в різні країни світу, в тому числі вони $є$ цінними складовими колекційного фонду Національного ботанічного саду ім. М.М. Гришка НАН України (НБС) [1-6].

До початку XX століття селекційна робота $з$ півоніями проводилася в межах одного виду - P. lactiflora. Перші спроби отримати міжвидові гібриди увінчалися успіхом у Європі. Французький селекціонер V. Lemoine в 1880-1890 роках провів успішне схрещування двох видів P. lactiflora i P. witmanniana Hartw. У Німеччині G. Arends отримав гібриди між P. peregrina Mill. i $P$. witmanniana, a англійський селекціонер P. Barr схрестив P. officinalis L. і P. arietina Anderson. Найбільш вагомий внесок у здійснення міжвидової гібридизації півоній зробили американські селекціонери M. Glasscok, M. Auten, W. Mains, W. Bockstoce, W. Krekler, M. Freeborn і особливо професор A. Saunders, який, за висловом Y. Wuster, створив більше нових гібридних форм і сортів півоній, ніж усі селекціонери минулого і сьогодення разом узяті. Перші результати його селекційної роботи демонструвалися на спеціалізованій виставці в Бостоні (1928 р.) [6].

Інтродукція рослин сприяє розширенню асортименту тієї чи іншої культури. Світовий досвід розвитку всіх галузей рослинництва показує, що перед тим, як починати широкі селекційні роботи зі створення власних місцевих сортів, необхідно за допомогою інтродукційних методів залучити якомога повніше видове і сортове розмаїття конкретної культури. Це збереже час і засоби для досягнення поставленої мети i підвищить ефективність селекційних робіт, оскільки вони будуть проводитися на більш високому рівні, досягнутому селекціонерами інших країн. Керуючись цією ідеєю і енергійно втілюючи іiі на практиці, видатний учений академік M.I. Вавилов багато років свого життя присвятив пошукам і залученню світових рослинних ресурсів, що на тривалий період визначило успіхи селекції багатьох культур $[7,8]$.

Становлення і розвиток селекційних досліджень у НБС пов'язані з ім'ям першого післявоєнного директора - академіка Миколи Миколайовича Гришка, оскільки асортимент квітково-декоративних рослин у той час був дуже бідним. Унікальні колекції квітководекоративних рослин, що зібрані у відділі квітникарства з різних ботаніко-географічних регіонів світу, стали основою для створення нових сортів і гібридів.

\section{Матеріали і методи}

Вихідним матеріалом для селекційного процесу слугували сорти P. lactiflora, P. officinalis 'Rubra Plena', дикорослі види з різних кліматичних регіонів світу ( $P$. anomala L., P. arietina Anderson, P. humilis Retz., P. steveniana (Stev.) Kem.-Nath., P. officinalis L., $P$. officinalis var. banatica L., P. peregrina Mill., P. wittmanniana

(С) ГОРОБЕЦЬ В.Ф. 
Hartw.), які починають цвісти на два тижні paніше сортів $P$. lactiflora.

Колекція півоній НБС нараховує 10 видів, 650 сортів. Колекція $\epsilon$ найбільшою в Україні і однією 3 найбагатших серед країн ближнього зарубіжжя та Східної Свропи. У ній представлені сорти всіх садових груп як в історичному плані, так і на рівні найсучасніших досягнень світової селекції. Колекція служить базою для проведення різнопланових наукових досліджень i еталоном, на тлі якого проходить державна експертиза нових сортів $[9,10]$.

При створенні нових сортів трав'янистих півоній були використані методи аналітичної селекції - масовий посів насіння від вільного запилення та синтетичної селекції, яка грунтується на використанні для добору вихідного матеріалу, створеного гібридизацією різних видів, сортів і форм. Для отримання гібридів у селекційній роботі були використані різні види схрещувань: міжвидові, насичувальні, полігібридні, реципрокні $[7,8]$.

\section{Результати та обговорення}

Першим етапом селекційної роботи в НБС було створення гібридного фонду на основі сортів півонії молочноквіткової (P. lactiflora). В результаті кропіткої роботи канд. біол. наук К.Д. Харченко було створено перші 12 сортів: 'Антарктида', 'Берегиня', 'Либідь', 'Дар Победе', 'Исполин', 'Київська Русь', 'Улюбленець парків', 'Морозно', 'Мрія', 'Визволителям Києва', 'Полярна Зірка', 'Талісман' (1984-1987 pp.) [11].

Використовуючи біологічні особливості видів роду Paeonia L., програму другого етапу нашої селекційної роботи з 1971 року склало створення сортів із надраннім і раннім терміном цвітіння. Програма, за якою велися роботи із селекції півоній, передбачала створення сортів 3 такими властивостями:

- надранній та ранній термін цвітіння;

- оригінальна форма і забарвлення квітки;

- високий коефіцієнт розмноження і продуктивність цвітіння;

- стійкість до вірусних, бактеріальних $\mathrm{i}$ грибних захворювань;

- придатність у декоративному садівництвi.

Це можна було здійснити тільки з використанням у селекції віддаленої гібридизації. В селекційний процес були залучені дикорослі види трав'янистих півоній із колекційних фондів НБС [10].

Природні види півоній можна розподілити на дві групи залежно від числа хромосом: 10-20 (диплоїдне число) або 5-10 (гаплоїдне число). Для селекції приналежність до певної групи має велике значення. Загальна кількість видів, підвидів і різновидів роду Paeоnia сьогодні складає 58 [2]. Найбільше число видів, підвидів і різновидів належить до групи півоній з 10 хромосомами, а 20-хромосомна група представлена лише 8 видами (табл. 1).

Сорт півоній - це розмножений вегетативним шляхом сіянець, отриманий шляхом гібридизації або відібраний із сіянців від вільного запилення, має високі декоративні та господарсько-цінні властивості.

Таблиця 1. Розподіл видів роду Paeonia L. за кількістю хромосом*

\begin{tabular}{|l|l|l|}
\hline \multicolumn{2}{|c|}{ Група із 10 хромосомами } & Група із 20 хромосомами \\
\hline P. anomala & & \\
P. corsica & P. suffruticosa & P. officinalis \\
P. broteroi & P. decomposita & P. peregrina \\
P. rodia & P. delavayi & P. parnassica \\
P. daurica & P. lutea & P. clusii \\
P. mairei & P. potanini & P. mascula \\
P. emodi & P. tenuiofolia & P. coriacea \\
P.mlokosewitschii & P. veichii & P. obovata \\
P. lactiflora & P. brownii & P. wittmanniana \\
\hline
\end{tabular}

Примітка. $* 2 n=10,20$.

У селекційній роботі були використані вітчизняні та закордонні сорти 3 різних екологогеографічних районів, види та селекційні фор- ми, отримані нами у попередні роки. Для збагачення вихідного генофонду було отримано серію гібридів із використанням різних методів 
селекції. При цьому ми враховували такі генетико-біологічні властивості півоній, як здатність до вегетативного розмноження, гетерозиготність сортів, частий прояв стерильності гібридного покоління через різну плоїдність вихідних батьківських форм або погане схещування багатьох видів із сортами P. lactiflora і $P$. officinalis.

Вегетативне розмноження півоній дозволяє відібрати будь-яку цінну стерильну або фертильну форму в $\mathrm{F}_{1}$, оцінити iii $\mathrm{i}$ впровадити у виробництво, що неможливо 3 культурами насіннєвого розмноження. Таким чином, родоначальником нового сорту півоній стає лише один найкращий відібраний сіянець. Потім рослину розмножують шляхом поділу, даючи початок потомству - клону, тобто клон - це вегетативно розмножене потомство однієї спочатку взятої маточної рослини.

Однією з особливостей селекції півоній $€$ значна тривалість періоду від посіву гібридного насіння до цвітіння, що затримує розробку рекомендацій із добору вихідних батьківських пар для схрещування. Створення нового сорту півоній - складний процес, що включає ряд етапів (розробка моделі майбутнього сорту, добір пар для гібридизації, вирощування сіянців, їх вивчення, розмноження нового сорту). Заключним етапом $\epsilon$ підготовка пакета документації про визнання прав на сорт і передача його в Держа- вну службу з охорони прав на сорти рослин. Від схрещування батьківської пари до реєстрації нового сорту півонії проходить, як правило, 2025 років.

Досвід селекційної роботи свідчить про те, що з багатьох комбінацій схрещувань лише окремі можуть дати початок довгостроковому плідному формотворному процесу або сприяти прояву принципово нових цінних ознак. Успіх гібридизації значною мірою залежить від правильного підбору пар для схрещування. 3 критеріїв, перш за все, враховують такі: екологогеографічні особливості, характер елементів декоративності, термін і продуктивність цвітіння, репродуктивну і регенераційну здатність, стійкість до шкідників і хвороб.

У результаті проведеної гібридизації було отримано серію віддалених гібридів 3 принципово новими донорськими ознаками за будовою, оригінальностю та чистототою забарвлення квітки, які ще не траплялися у наявних сортів P. lactiflora. Особливо цінним $є$ те, що у відібраних гібридів ці якості поєднані з надраннім і раннім цвітінням. Останній властивості ми приділяли особливу увагу в селекційній роботі.

Аналіз гібридного фонду, отриманого від віддалених схрещувань, дозволив виділити комбінації, які дають фертильне потомство:

- + P.officinalis 'Rubra Plena' $\times \precsim P$. peregrina,

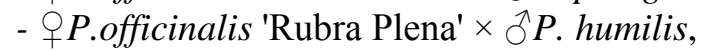

- P P.officinalis 'Rubra Plena' $\times \widehat{\partial}$ P. officinalis var.alba,

- + P. officinalis 'Rubra Plena' $\times \widehat{O} P$. officinalis var. banatica.

Більшість сортів $P$. lactiflora нам вдалося схрестити з віддаленими гібридами $\mathrm{F}_{1}$ (P. officinalis 'Rubra Plena' $\times P$. peregrina) i отримати потрійні віддалені гібриди. Потрійні віддалені гібриди отримано від схрещування $\mathrm{F}_{1}(P$. officinalis 'Rubra Plena' $\times P$. peregrina $), \mathrm{F}_{1}(P$. officinalis 'Rubra Plena' $\times$ P. humilis $), \mathrm{F}_{1}(P$. officinalis 'Rubra Plena' $\times$ P. officinalis v.alba) $3 P$. steveniana (табл. 2).

У результаті вивчення гібридного фонду виділено види, сорти і пари комбінацій, при гібридизації яких можна отримати форми 3 комплексом цінних ознак. Встановлено, що сіянці в більшості випадків успадковують такі ознаки, як міцність стебел, висоту рослин, високу пагоноутворюючу здатність, стійкість до несприятливих факторів, саме від батьківської форми P. lactiflora.

\section{Висновки}

Нами встановлено, що найбільш декоративні форми півоній із махровими або напівмахровими квітками можна отримати, використовуючи як материнський компонент $P$. officinalis 'Rubra Plena' 3 махровими квітками, а батьківський - сорти P. lactiflora також з махровими квітками. Наприклад, сорт 'Ювілей Києва' створений шляхом схрещування $P$. officinalis 'Rubra Plena' i3 $P$. lactiflora 'Adolphe Roussean', copт Бенефіс - шляхом схрещування $P$. officinalis 'Rubra Plena' та P. lactiflora 'President Taft'. Іноді вдається отримати махрові форми при схрещуванні $P$. officinalis 'Rubra Plena' 3 сортами або селекційними номерами $P$. lactiflora, які мають немахрові квітки. Саме таким чином отримано сорт 'Чаклунка'. 
Таблиця 2. Генезис сортів півонії селекції НБС, створених з використанням методу віддаленої гібридизації.

\begin{tabular}{|c|c|c|}
\hline Сорт & $\begin{array}{l}\text { Рік пріорите- } \\
\text { ту сорту }\end{array}$ & Комбінації схрещувань \\
\hline \multicolumn{3}{|c|}{ Подвійні міжвидові гібриди } \\
\hline Бенефіс & 2003 & $\begin{array}{l}\text { O P.officinalis 'Rubra Plena' } \times \widehat{\jmath} \text { P.lactiflora 'President } \\
\text { Taft' }\end{array}$ \\
\hline Блондин & 2013 & Q P.officinalis 'Rubra Plena' $\times \hat{\jmath}$ P.lactiflora \\
\hline Весняне Дефіле & 2014 & Q P.officinalis 'Rubra Plena' $\times \hat{\widehat{\lambda} P .}$ wittmanniana \\
\hline Кокетка & 2011 & $\begin{array}{l}\text { O P.officinalis var.banatica } \times \widehat{\jmath} \text { P.lactiflora 'President } \\
\text { Taft' }\end{array}$ \\
\hline Корифей & 2003 & I P. peregrina $\times \hat{o}$ P.lactiflora 'President Taft' \\
\hline Малинова Ватра & 2010 & Q P.peregrina $\times \widehat{\S}$ P. lactiflora 'La Pionce' \\
\hline Офелія & 1998 & 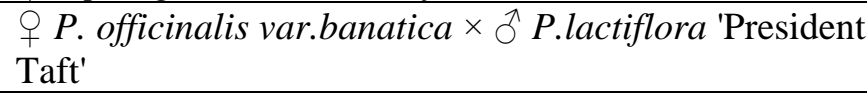 \\
\hline Світлячок & 2013 & 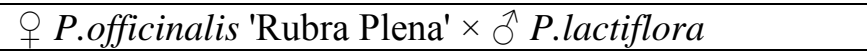 \\
\hline Травневі Роси & 2013 & 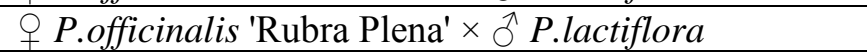 \\
\hline Фаворит & 2009 & 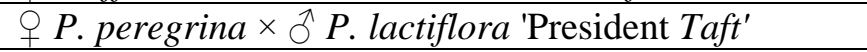 \\
\hline Хохлома & 1986 & O P.officinalis 'Rubra Plena' $\times \hat{~} \hat{\text { P P.lactiflora }}$ \\
\hline Чаклунка & 2003 & Q P.officinalis 'Rubra Plena' $\times \hat{\widehat{O}}$ P.lactiflora \\
\hline Чебурашка & 2011 & O P. officinalis 'Rubra Plena' $\times \delta^{\lambda} P$. peregrina \\
\hline Червоний Оксамит & 1984 & Q P. peregrina $\times \widehat{O}^{\wedge}$ P.lactiflora 'President Taft' \\
\hline Червоні Вітрила & 1998 & Q P.officinalis 'Rubra Plena' $\times \hat{o}$ P.lactiflora \\
\hline Чумацький Шлях & 2010 & Q P. lactiflora 'Lord Kitchener' $\times \widehat{\jmath} P$. arietina \\
\hline Ювілей Києва & 2003 & 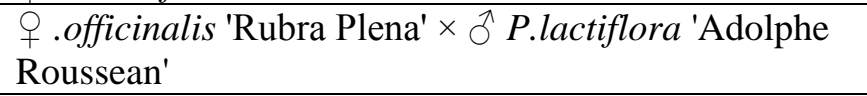 \\
\hline \multicolumn{3}{|c|}{ Потрійні міжвидові гібриди } \\
\hline Геркулес & 2010 & $\begin{array}{l}\text { O P. lactiflora 'Adolphe Roussean' } \times \\
\hat{\partial}(P . \text { officinalis 'Rubra Plena' } \times P . \text { peregrina })\end{array}$ \\
\hline Героям Небесної Сотні & 2014 & $\begin{array}{l}\text { O P.lactiflora 'Lord Kitchener' } \times \\
\overbrace{}^{\lambda} \mathrm{F}_{1}(\text { P. officinalis 'Rubra Plena' } \times \text { P. peregrina })\end{array}$ \\
\hline Квазімодо & 2010 & $\begin{array}{l}\text { O P. lactiflora } \text { 'M-lle Janne Riviere' } \times \\
\delta \mathrm{F}_{1}(\text { P. officinalis 'Rubra Plena' } \times \text { P. peregrina })\end{array}$ \\
\hline Писанка Коломиї & 2010 & $\begin{array}{l}\text { O P. lactiflora 'Adolphe Roussean' } \times \\
\text { O } \mathrm{F}_{1}(\text { P.officinalis 'Rubra Plena' } \times \text { P.peregrina) }\end{array}$ \\
\hline Чемпіон & 2009 & $\begin{array}{l}\text { O P. lactiflora 'Adolphe Roussean' } \times \\
\partial^{\lambda} \mathrm{F}_{1}\left(\text { P.officinalis 'Rubra Plena' } \times \hat{O}^{\lambda} \text { P.peregrina }\right)\end{array}$ \\
\hline Червона Вежа & 2009 & $\begin{array}{l}\text { O P. lactiflora 'Adolphe Roussean' } \times \\
\hat{\partial} F_{l}\left(\text { P.officinalis 'Rubra Plena' } \times \hat{O^{\lambda}} \text { P.peregrina }\right)\end{array}$ \\
\hline Ірокез & 2007 & $\begin{array}{l}\text { O P. lactiflora 'Lord Kitchener' } \times \\
\partial \mathrm{F}_{1}(P . \text { officinalis 'Rubra Plena' } \times \text { P. officinalis } \\
\text { var.banatica })\end{array}$ \\
\hline Метелик & 2009 & $\begin{array}{l}\text { P P.lactiflora 'Lord Kitchener' } \times \overbrace{}^{\lambda} \mathrm{F}_{1}(\text { P.officinalis } \\
\text { 'Rubra Plena' } \times \widehat{0} \text { P.officinalis var.banatica })\end{array}$ \\
\hline Світанкова Поема & 2011 & 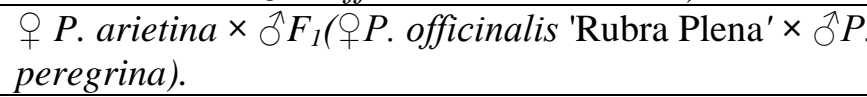 \\
\hline
\end{tabular}


Виявлено великі формоутворюючі можливості віддаленої гібридизації, які полягають не тільки в поєднанні корисних ознак вихідних форм, але і появі багатьох нових, не властивих батьківським. Характер і амплітуда мінливості при цьому залежать від комбінації схрещувань.
Гібридний потенціал півоній НБС дуже великий, і робота із селекції нових сортів триває.

У Державний реєстр сортів рослин, придатних для поширення в Україні, занесено 32 сорти півонії селекції НБС, з них 26 створено 3 використанням у селекції методу віддаленої гібридизації.

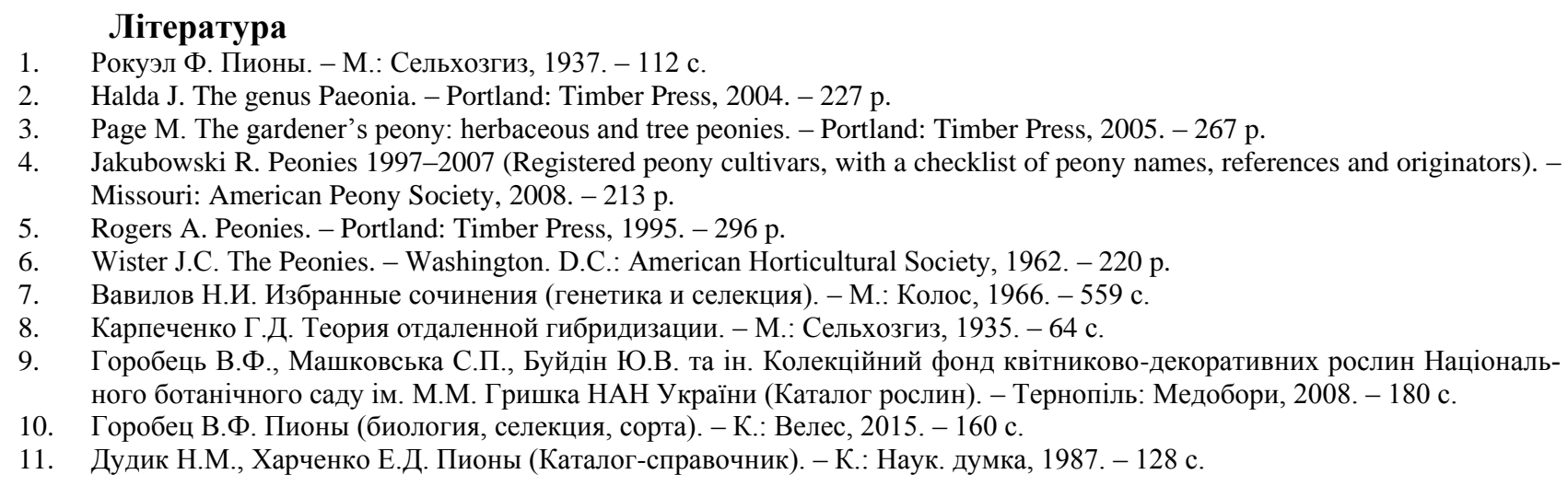

GOROBETS V.F.

M.M. Grysko National Botanical Gardens,

Ukraine, 01014, Kyiv, Timiryazevska str., 1, e-mail: passer-w@yandex.ua

\section{THE CREATION OF THE DOMESTIC VARIETIES OF PEONY USING THE METHOD OF DISTANT HYBRIDIZATION}

Aim. The creation of the domestic varieties of herbaceous peonies, early flowering period, with the original shape and color of the flower that are resistant to viral, bacterial and fungal diseases. Methods. To obtain hybrids were used different types of crosses: interspecific, recurrent, polyhybrid, reciprocal. Results. As a result of hybridization was obtained a series of distant hybrids with fundamentally new donor characteristics in the structure, originality and color purity of the flower, which had not met in varieties of $P$. lactiflora. Especially valuable is the fact that in selected hybrids of these qualities combined with very early and early flowering. Conclusions. Discovered large the forming capabilities of the distant hybridization, which are not only in the combination of useful traits of the original forms, but also the emergence of many new, not peculiar to the parent. The nature and amplitude of variability depends on the combinations of crosses. In the State register of plant varieties suitable for distribution in Ukraine included 32 varieties of peony breeding NBG, 26 of them were created using the selection method of distant hybridization. Keywords: selection, variety, species, a gene pool, the remote hybridization. 